\title{
Palaeoenvironmental reconstruction based on the Early Holocene Haelen sequence, near Roermond (southeastern Netherlands)
}

\section{Johanna A.A. Bos ${ }^{1, *} \&$ Bas van Geel ${ }^{2}$}

1 ADC ArcheoProjecten, Nijverheidsweg-Noord 114, 3812 PN Amersfoort, The Netherlands

2 Research Group Palaeoecology and Landscape Ecology, Institute for Biodiversity and Ecosystem Dynamics, University of Amsterdam, Science Park 904, 1098 XH Amsterdam, The Netherlands

* Corresponding author. Email: h.bos@archeologie.nl

Manuscript received: 22 December 2015, accepted: 31 July 2016

\section{Abstract}

High-resolution Early Holocene palynological records from the middle Meuse River valley were missing until recently. In order to investigate environmental and inferred climate changes during the Preboreal, sediments from a former residual channel of the Meuse River near Haelen were studied. Detailed multi-proxy analyses, including microfossils, macroremains and loss-on-ignition measurements, were carried out at a high temporal resolution. An accurate chronology of the $>1000$-year-long record was provided by accelerator mass spectrometry (AMS) ${ }^{14} \mathrm{C}$ wiggle-match dating.

The channel was abandoned during the late Younger Dryas, when accumulation started with gyttja. This period was characterised by an open landscape with herbaceous vegetation and dwarf shrubs. Patches of birch were present on the floodplains around depressions and (oxbow) lakes. Some pines survived the cold in sheltered locations. In the residual channel the water was flowing temporarily and aquatic plant communities developed with predominantly submerged taxa and algae. The shores were fringed by willows and sedges and were probably used as a watering place by large herbivores.

Following the Late-glacial/Holocene climate warming, dated in the Haelen record around 11,520 cal BP, birch woodlands expanded on the river floodplains and slopes of terraces during the Friesland Phase. Open vegetation with herbs and juniper remained present on the nearby terraces. An increase in the water level of the oxbow lake and seepage of groundwater occurred. Along the shores herbaceous vegetation was present. Around 11,420 cal BP, birch expansion was interrupted by the dry continental Rammelbeek Phase. On the river floodplain and terrace slopes, open grassland vegetation developed and on the terraces, grasslands and open grounds were abundant. In the residual channel the water became stagnant and floating-leaved vegetation developed. At the start of the Late Preboreal, around 11,270 cal BP, a sudden shift to a more humid climate took place and birch forests expanded again on the river floodplains and terrace slopes. Poplar became more abundant in these forests, and birch and poplar swamp forests were present near the site. Pine expanded at c. 11,160 cal BP on the higher sandy and gravelly terraces. During the Late Preboreal a reed swamp developed on the shores of the residual channel.

At the onset of the Boreal, around 10,710 cal BP, woodlands, initially with hazel, but later also with oak, elm and lime, started to develop, while pine forest remained present on the higher terraces. Hazel shrubs were growing on the terrace slopes. Birch and poplar forests occurred on moist parts of the floodplains. Around the residual channel they formed a zone behind the reed swamps surrounding the oxbow lake. Vegetation with water lilies was present in open water.

The Haelen record shows, despite a lack of archaeological evidence, indications for the presence of Mesolithic people in the area during the Preboreal. These include the occurrence of (natural or man-made) fires, in combination with the presence of trampled areas and disturbed grounds and possibly consumption of Nymphaeaceae seeds and tubers.

Keywords: high-resolution analysis, Mesolithic, multi-proxy record, The Netherlands, pollen and macrofossils, Preboreal 


\section{Introduction}

During the Early Holocene several short climatic oscillations occurred (e.g. Wijmstra \& de Vin, 1971; van Geel et al., 1981; Hoek, 1997a; Bos et al., 2007). Based on changes in the forest composition (AP) and herbaceous vegetation (NAP), the Preboreal biozone in the Netherlands is subdivided into the Friesland Phase, the Rammelbeek Phase and the Late Preboreal (e.g. Behre 1966, 1978; Wijmstra \& de Vin, 1971; van Geel et al., 1981). The Friesland Phase (Behre, 1966) was a period of rising mean summer and winter temperatures. In NW Europe January temperatures increased from values between $-25^{\circ} \mathrm{C}$ and $-15^{\circ} \mathrm{C}$ in the Younger Dryas to between $-5^{\circ} \mathrm{C}$ and $5^{\circ} \mathrm{C}$ in the Preboreal (Renssen \& Isarin, 2001). During July the changes were smaller, as the July temperatures increased in NW Europe by $3-5^{\circ} \mathrm{C}$ from about $10-15^{\circ} \mathrm{C}$ in the Younger Dryas to values of $13-17^{\circ} \mathrm{C}$ in the Preboreal (Renssen \& Isarin, 2001). The Friesland Phase in the Netherlands was characterised by a strong expansion of birch woodlands (van Geel et al., 1981; Bos et al., 2005a, 2007). The Rammelbeek Phase is regarded as a dry and continental phase, with warm summers and cold winters and a temporary expansion of steppe-like grasslands (van Geel \& Kolstrup, 1978; van Geel et al., 1981). The start of the Late Preboreal was characterised in the Netherlands by a change to a wetter climate, probably forced by a sudden decline in solar activity (van der Plicht et al., 2004; Bos et al., 2007), and an expansion of birch forests. In the Netherlands, the vegetation response to these Early Holocene climate changes was regionally different and dependent on the geomorphology of the landscape (Hoek, 1997a,b; Bos et al., 2007; Hoek et al., 2016.). Also in the Meuse River valley these climate changes had their impact on the vegetation and river course, which will be discussed in this paper.

The Meuse River valley in the Netherlands can be subdivided into northern, middle and southern parts. The northern part of the Meuse valley, or so-called Sand Meuse ('Zandmaas'), is located between Venlo and Nijmegen. The middle part of the Meuse valley falls between Venlo and Sittard, and the southern part is located between Sittard and Maastricht (cf. Zuidhoff \& Huizer, 2015). Teunissen (1983, 1990) performed detailed palynological research on a number of channel fills from the northern Meuse valley, in order to reconstruct the vegetation development of this area during the Late-glacial and Holocene. Furthermore, over recent decades, a large number of palynological studies and prospecting scans have been performed in this area in order to date and reconstruct the development of the river valley and its vegetation history. In some cases, these studies were also supported by radiocarbon dating (Bos, 1992; Zuidhoff \& Huizer, 2015; Hoek et al., 2016). Most recently, extensive palynological studies on residual channel fills of the Meuse River were carried out in this area in combination with archaeological and geomorphological research, such as near Lomm (e.g. Bos et al., 2012; F.S. Zuidhoff \& J.A.A. Bos, in prep.) and
Well-Aijen (van Haaster, 2011; Bos \& Zuidhoff, 2015). At these locations large water basins are being constructed as a passage for the Meuse River during high-water levels. This made further research in the area available. At Lomm the vegetation history during the Holocene was reconstructed based on a combination of several residual channel fills that reflect shorter time periods of the Holocene (Bos et al., 2008; Zuidhoff \& Bos, 2011a,b, 2016). The Well-Aijen sequence was analysed at a high resolution and dated by five accelerator mass spectrometry (AMS) radiocarbon dates. The continuous palynological record reflects the vegetation history from c. 10,000 BP onwards and ends during the early Roman period (Zuidhoff \& Bos, 2014; Bos \& Zuidhoff, 2015). The Well-Aijen pollen diagram may be regarded as a standard for the Meuse River valley.

From the middle Meuse River valley only a few records are available that reflect environmental response during the Early Holocene (e.g. Bohncke \& Hoek, 2007; Blokker, 2013; Buijs, 2013; 0tten, 2013). A high-resolution, accurately dated palaeoecological record, however, was missing. At Haelen, the Early Holocene is reflected in the deposits of a residual channel of the river Meuse (Bos et al., 2007). On the sediments of the Haelen sequence highly detailed botanical and zoological analyses (including pollen, spores, other microfossils and macroremains) and additional geochemical analyses (loss-on-ignition) were carried out at high resolution, and an accurate chronology of the record was provided by AMS wiggle-match dating (Bos et al., 2007). Furthermore, finds of archaeological remains near Haelen suggest that Mesolithic people were occupying the area from the Boreal onwards (Bats et al., 2010; Scheurs, 2013). Moreover, archaeological evidence from other sites in the Meuse River area suggests that groups of early Mesolithic people were already present in the Meuse valley during the Preboreal (Verhart, 2008; ter Wal \& Tebbens, 2012; Bouma \& Müller, 2014). It is thus possible that Mesolithic people also inhabited the Haelen area during the Preboreal, though no archaeological evidence has yet been found. During the Mesolithic the principal means of subsistence were hunting, fishing and gathering, all activities that had a supposedly small and local impact on the vegetation, difficult to detect in pollen diagrams. High-resolution studies (e.g. Simmons et al. 1989; Day 1993; Simmons 1993; Day \& Mellars 1994; Bos \& Urz 2003; Bos et al., 2005b) of pollen and non-pollen palynomorphs, such as at Haelen, may provide information about forest opening phases or the occurrence of human-induced fires or fire places.

In this paper we discuss the environmental history of the middle Meuse River valley and inferred climate changes during the Early Holocene as recorded in the Haelen sequence. The pollen record reflects the regional vegetation development of the area, while other microfossils (including non-pollen palynomorphs), macroremains and geochemical data provide information about the development of local environmental conditions of the site and possible human presence. 


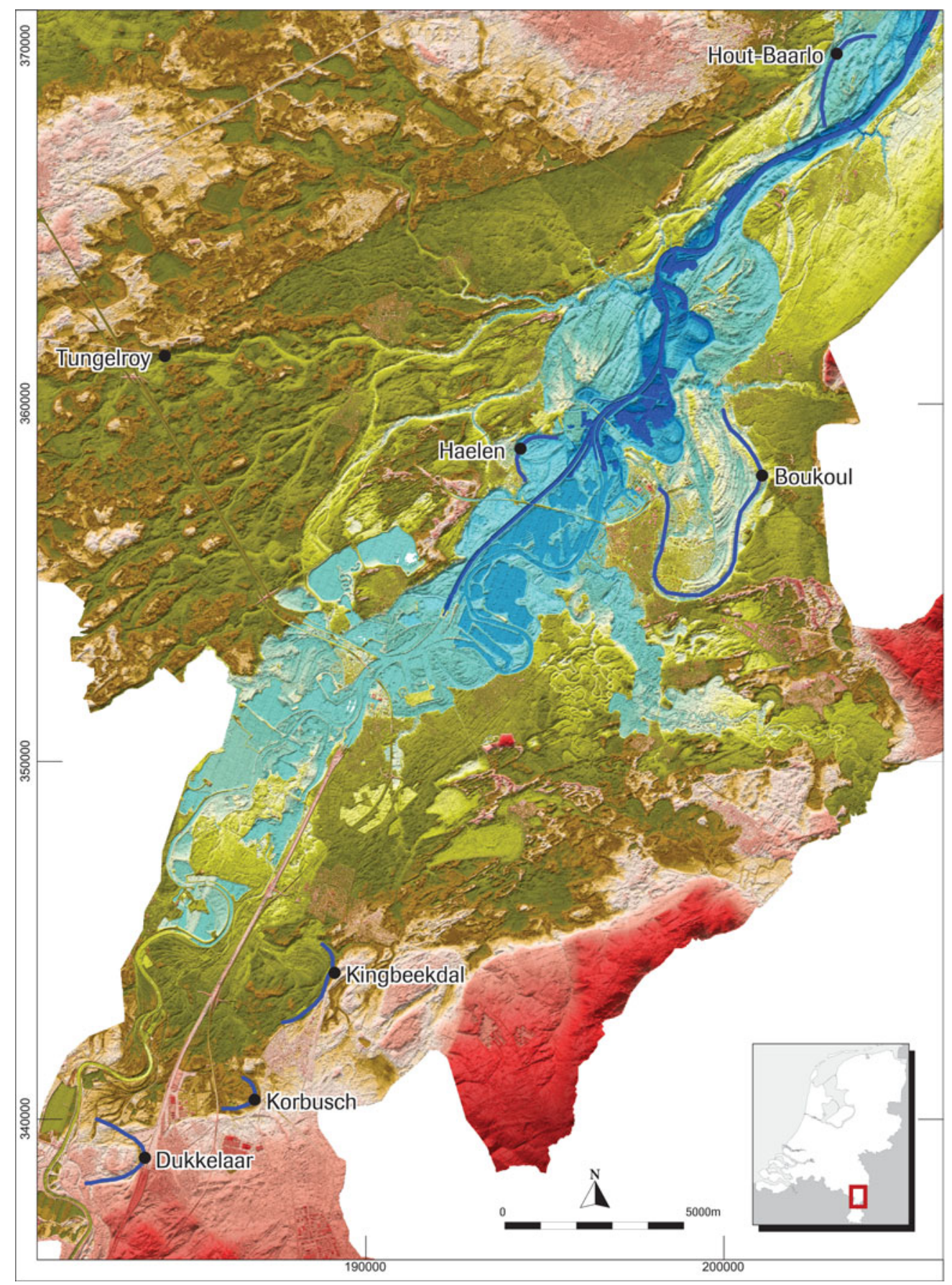

Fig. 1. Location of the Haelen site in the middle Meuse River valley. The locations of the other sites discussed in the text are also shown, including the Younger Dryas meanders of the river Meuse of Hout-Baarlo, Boukoul, Kingbeekdal, Korbusch and Dukkelaar (e.g. Bohncke \& Hoek, 2007; Buijs, 2013; Blokker, 2013; Otten, 2013). The location of the Tungelroyse beek (Woelders et al., 2015) in the southern coversand region of the Netherlands is also shown.

\section{Study area}

The sediment sequence of Haelen $\left(51^{\circ} 13^{\prime \prime \prime} 55^{\prime \prime} \mathrm{N}, 5^{\circ} 58^{\prime} 51^{\prime \prime} \mathrm{E}\right)$ was collected from a residual channel of the river Meuse near Roermond, SE Netherlands (Fig. 1). The former river channel had eroded westward far into the southern coversand region and was originally probably c. $10 \mathrm{~m}$ deep and $80 \mathrm{~m}$ wide. The channel became abandoned at the end of the Younger
Dryas and sedimentation started under lacustrine conditions. Accumulation of gyttja was followed during the Boreal by formation of peat (Bos et al., 2007). Accumulation ceased during the Atlantic (c. $6000{ }^{14} \mathrm{C} \mathrm{BP}$ ) but restarted around $4000{ }^{14} \mathrm{C}$ BP (Verbruggen et al., 2003). The top of the deposit dates at $1920 \pm 35 \mathrm{BP}$ (AD 0-170). Later deposits are probably missing due to peat digging (Verbruggen et al., 2003). 


\section{Methods}

\section{Botanical analysis}

Subsamples were taken every $\mathrm{cm}$ from the Haelen sediment core for high-resolution microfossil (pollen, spores, fungi, algae, etc.), macroremain (seeds, fruits, wood, mosses, etc.) and LOI analyses. Microfossil subsamples were collected using a small corer of defined volume $\left(\sim 280 \mathrm{~mm}^{3}\right)$ and prepared following Faegri \& Iversen (1989) and heavy liquid separation in addition. Sieving was carried out using a $215 \mu \mathrm{m}$ sieve. $L y$ copodium spores were added to calculate pollen concentrations. The residues were mounted in glycerine. A Leica light microscope (magnification $400 \times$ and $1000 \times$ ) was used for microfossil analysis. Preservation in general was excellent. Pollen types were identified by comparison with modern reference material and identification keys of Moore et al. (1991) and the Northwest European Pollen Flora, vols I-VIIII (Punt et al., 1976-2003). Nomenclature follows these keys. Other microfossils were identified using van Geel (1978, 2001), van Geel et al. (1981, 1983, 1989, 2003), Francis (2001), Komárek \& Jankovská (2001) and van Geel \& Aptroot (2006).

Macroremain subsamples were boiled in $5 \% \mathrm{KOH}$ for c. $5 \mathrm{~min}$ and washed over a 75-80 $\mu \mathrm{m}$ sieve. Macroremains were picked out from the recovered fraction and stored at $4^{\circ} \mathrm{C}$. For screening and selection a Leica dissection microscope (magnification 8-100x) was used. Plant macrofossil identifications were made by comparison with modern reference material and identification keys of Beijerinck (1947), Nilsson \& Hjelmqvist (1967), Berggren (1969, 1981), Schweingruber (1978) and Anderberg (1994). Nomenclature follows van der Meijden (1996).

The combined microfossil and macroremain diagram and a concentration diagram were constructed using the Tilia and Tg.view computer programs (Grimm, 1991-2004). Combined arboreal pollen (AP) and non-arboreal pollen (NAP) totals were employed for percentage calculations. Pollen and spores of the local aquatic or mire vegetation (inclusive Cyperaceae) and redeposited palynomorphs of thermophilous taxa were excluded (cf. Janssen, 1973; Bos, 1998). Redeposited palynomorphs of thermophilous taxa were mainly recorded in the more minerogenic lower part of the record. Zonation of the diagram was based on changes in the AP/NAP ratio and trends in the percentages of arboreal taxa that dominate Late-glacial - Early Holocene pollen records of NW Europe.

\section{Chronology}

In order to provide an accurate chronology for the Haelen record, samples of organic material reflecting atmospheric ${ }^{14} \mathrm{C}$ concentrations, such as seeds and fruits from terrestrial plants, were selected for radiocarbon dating. From the Haelen site a series of 28 AMS ${ }^{14} \mathrm{C}$ radiocarbon dates was available (Table 1; Bos et al., 2007). Radiocarbon dates were converted into cal- endar years using visual wiggle-match dating (WMD) (e.g. van Geel \& Mook, 1989; Blaauw et al., 2003, 2004). A WMD-based chronology for the Haelen record was obtained from c. 11,520 to 10,530 cal BP and was published by Bos et al. (2007). An accumulation rate of $10.3 \mathrm{yr} \mathrm{cm}^{-1}$ was calculated. Absolute ages in this paper are reported in cal BP, i.e. calibrated or calendar age relative to $\mathrm{AD} 1950$.

\section{Loss-on-ignition and tephra analysis}

Loss-on-ignition (LOI) analysis was carried out to provide a measure of the organic $C$ content of the sediments. Sediment samples of a few $\mathrm{cm}^{3}$ were dried overnight in crucibles at $105^{\circ} \mathrm{C}$ to remove any moisture, cooled in a desiccator and weighed. The sample plus crucible were then put into the furnace at $550^{\circ} \mathrm{C}$ for 4 hours for ashing of the organic matter. Once ashing was completed the crucibles were cooled in a desiccator and re-weighed to provide a measure of LOI.

From the Haelen sequence $(355-395 \mathrm{~cm}$ depth) also $1 \mathrm{~cm}$ thick samples were checked for the presence of microtephra. Microscopic tephra layers can be used as chronological marker horizons, which may enable correlation of the Haelen record with other European records (Davies et al., 2002, 2005) and the Greenland ice-core records (e.g. Dansgaard et al., 1993; Johnsen et al., 1997; NGRIP members, 2004; Rasmussen et al., 2006, 2007, 2013). However, although a few possible tephra particles were found, no distinct layers were present (S. Davies, pers. comm., 2012).

\section{Results and interpretation}

The Haelen microfossil and macroremain diagram (Fig. 2a-e) covers the late Younger Dryas to early Boreal biozones (cf. van Geel et al., 1981; Hoek, 1997a). A WMD chronology is given for the period 11,520-10,530 cal BP (Bos et al., 2007). The zone boundaries (in cal BP) for the Haelen record are displayed in Table 2. Furthermore a concentration diagram is presented showing a selection of curves (Fig. 3 ). The concentration diagram demonstrates that the high concentrations of all taxa during the Younger Dryas are in strong contrast to the much lower values during the Early Holocene. This indicates that the accumulation rate during the Younger Dryas was low but strongly increased during the Early Holocene as a result of an increase in biological productivity. The regional development around Haelen in the middle Meuse valley, and the local vegetation succession in the Haelen residual channel, are discussed below.

\section{Regional vegetation development}

Younger Dryas Due to the absence of datable botanical material, the start of the Haelen record could not be radiocarbon-dated. 
Table 1. AMS radiocarbon dates of the Haelen record. GrA: Radiocarbon Laboratory of the Centre for Isotope Research, Groningen, the Netherlands. KIA: Leibniz Labor, Kiel, Germany.

\begin{tabular}{|c|c|c|c|c|c|}
\hline Depth (cm) & Serie Nr. & Lab. Nr. & ${ }^{14} \mathrm{C}$ age $\mathrm{BP}$ & Dated material & $\delta^{13} \mathrm{C}$ value \\
\hline 293 & 2 & GrA-26051 & $9380 \pm 60$ & $\begin{array}{l}\text { Betula alba; } 20 \text { fruits, } 8 \text { female catkin scales, } 2 \text { male catkin scales, } 1 \text { bud } \\
\text { scale; Pinus; } 8 \text { scale leaves }\end{array}$ & -27.93 \\
\hline 299 & 2 & GrA-26052 & $9530 \pm 70$ & Betula alba; 4 fruits, 13 female scale leaves & -27.35 \\
\hline 303 & 1 & GrA-25203 & $9490 \pm 50$ & Betula alba; 5 female catkin scales, Pinus; 8 scale leaves & -28.38 \\
\hline 304 & 3 & KIA-20867 & $9320 \pm 45$ & Selected macroremains & - \\
\hline 309 & 2 & GrA-26053 & $9410 \pm 60$ & Betula alba; 1 female catkin scale, 10 fruits, Pinus; 9 scale leaves, 1 needle & -28.36 \\
\hline 311 & 1 & GrA-25201 & $9500 \pm 60$ & Pinus; 14 scale leaves & -27.98 \\
\hline 313 & 2 & GrA-26055 & $9500 \pm 60$ & $\begin{array}{l}\text { Betula alba; } 14 \text { fruits, } 2 \text { female catkin scales, } 1 \text { bud scale, Populus; } 1 \\
\text { catkin scale, } 2 \text { bud scales }\end{array}$ & -28.96 \\
\hline 320 & 1 & GrA-25200 & $9440 \pm 50$ & Betula alba; 7 fruits, 13 female catkin scales, 1 male catkin scale & -27.99 \\
\hline 325 & 1 & GrA-25197 & $9420 \pm 60$ & Betula alba; 18 fruits, 2 female catkin scales, 1 male catkin scale & -28.47 \\
\hline 330 & 1 & GrA-25196 & $9450 \pm 60$ & Betula alba; 41 fruits, 15 female catkin scales, 2 bud scales & -28.69 \\
\hline 335 & 1 & GrA-25387 & $9480 \pm 70$ & Betula alba; 20 fruits, 4 female catkin scales, 1 bud scale & -28.15 \\
\hline 340 & 1 & GrA-25385 & $9180 \pm 60$ & Betula alba; 17 fruits, 4 female catkin scales, 3 bud scales & -27.82 \\
\hline 341 & 2 & GrA-26056 & $9460 \pm 60$ & $\begin{array}{l}\text { Betula alba; } 24 \text { fruits, } 4 \frac{1}{2} \text { female catkin scales, } 1 \text { male catkin scale, } 3 \text { bud } \\
\text { scales, Populus; } 1 / 4 \text { bud scale }\end{array}$ & -28.19 \\
\hline 345 & 1 & GrA-25384 & $9470 \pm 70$ & Betula alba; 14 fruits, 4 female catkin scales, Populus; 1 catkin scale & -28.32 \\
\hline 350 & 1 & GrA-25382 & $9330 \pm 60$ & Betula alba; 46 fruits, 1 female catkin scale, 1 bud scale & -28.29 \\
\hline 353 & 2 & GrA-26058 & $9730 \pm 70$ & Betula alba; 20 fruits, 2 female catkin scales, 1 bud scale & -31.86 \\
\hline 355 & 1 & GrA-25381 & $9810 \pm 80$ & $\begin{array}{l}\text { Betula alba; } 11 \text { fruits, } 3 \text { female catkin scales, } 1 \text { male catkin scale, } 2 \text { bud } \\
\text { scales, Populus; } 1 \text { catkin scale }\end{array}$ & -28.82 \\
\hline 360 & 1 & GrA-25365 & $9800 \pm 80$ & $\begin{array}{l}\text { Betula alba; } 12 \text { fruits, } 4 \text { female catkin scales, } 3 \text { male catkin scales, } 2 \text { bud } \\
\text { scales }\end{array}$ & -28.54 \\
\hline 363 & 2 & GrA-26059 & $10000 \pm 80$ & Betula alba; 4 fruits, 4 female catkin scales & -27.42 \\
\hline 365 & 1 & GrA-25364 & $9590 \pm 70$ & $\begin{array}{l}\text { Betula alba; } 5 \text { fruits, } 3 \text { female catkin scales, } 1 \text { male catkin scale, Populus; } \\
11 \frac{1}{2} \text { catkin scale }\end{array}$ & -28.01 \\
\hline 370 & 1 & GrA-25363 & $9500 \pm 60$ & Betula alba; 5 fruits, 2 female catkin scales & -29.43 \\
\hline 373 & 2 & GrA-26061 & $9970 \pm 70$ & Betula alba; 5 fruits, $3 \frac{1}{2}$ female catkin scales & -29.04 \\
\hline 375 & 1 & GrA-25362 & $9900 \pm 60$ & Betula alba; 6 fruits, 3 female catkin scales & -27.51 \\
\hline 380 & 1 & GrA-25359 & $9210 \pm 60$ & Betula alba; 17 fruits, 7 female catkin scales, 1 male catkin scale & -27.10 \\
\hline 381 & 3 & KIA-20893 & $9955 \pm 45$ & - & - \\
\hline 382 & 2 & GrA-26062 & $10100 \pm 90$ & Betula alba; 17 fruits, 4 female catkin scales, 2 bud scales & -27.84 \\
\hline 386 & 1 & GrA-24358 & $9410 \pm 70$ & Betula alba; 12 fruits, 4 female catkin scales & -27.23 \\
\hline $389-390$ & 2 & GrA-26063 & $10040 \pm 80$ & $\begin{array}{l}\text { Betula alba; } 11 \text { fruits, } 4 \frac{1}{2} \text { female catkin scales, } 2 \text { male catkin scales, } 1 / 2 \text { bud } \\
\text { scale, Betula nana; } 1 \text { fruit, } 1 \text { bud scale }\end{array}$ & -28.51 \\
\hline
\end{tabular}

However, the pollen assemblage clearly points to a late Younger Dryas age. Around Haelen the late Younger Dryas was characterised by an open landscape with herbaceous vegetation and dwarf shrubs such as Betula nana (dwarf birch), Salix (dwarf willow) and Juniperus communis (juniper). Furthermore, taxa such as Ribes nigrum (blackcurrant) and Ephedra distachyatype (sea grape) were probably present, but records of Ephedra pollen may also be the result of long-distance transport. However, Hoek (1997b) suggests that sea grape was probably locally present in the more sandy regions of the Netherlands. During this period, the number of trees was low, although macrofossils of Betula sect. Albae (tree birch) suggest that birch trees were growing in the woodland vegetation around the site. Pinus sylvestris (pine) probably remained present at sheltered locations (so-called local refugia).

In the Netherlands, especially during the later part of the Younger Dryas, Empetrum nigrum (crowberry) but also some Calluna vulgaris (heather) were important species in the open vegetation on the more acid and poor sandy soils (cf. Hoek, 1997a,b). Sandy soils however, were not so frequently available in the Meuse River area around Haelen. During the Younger Dryas, these were more common in the SW and NE coversand 


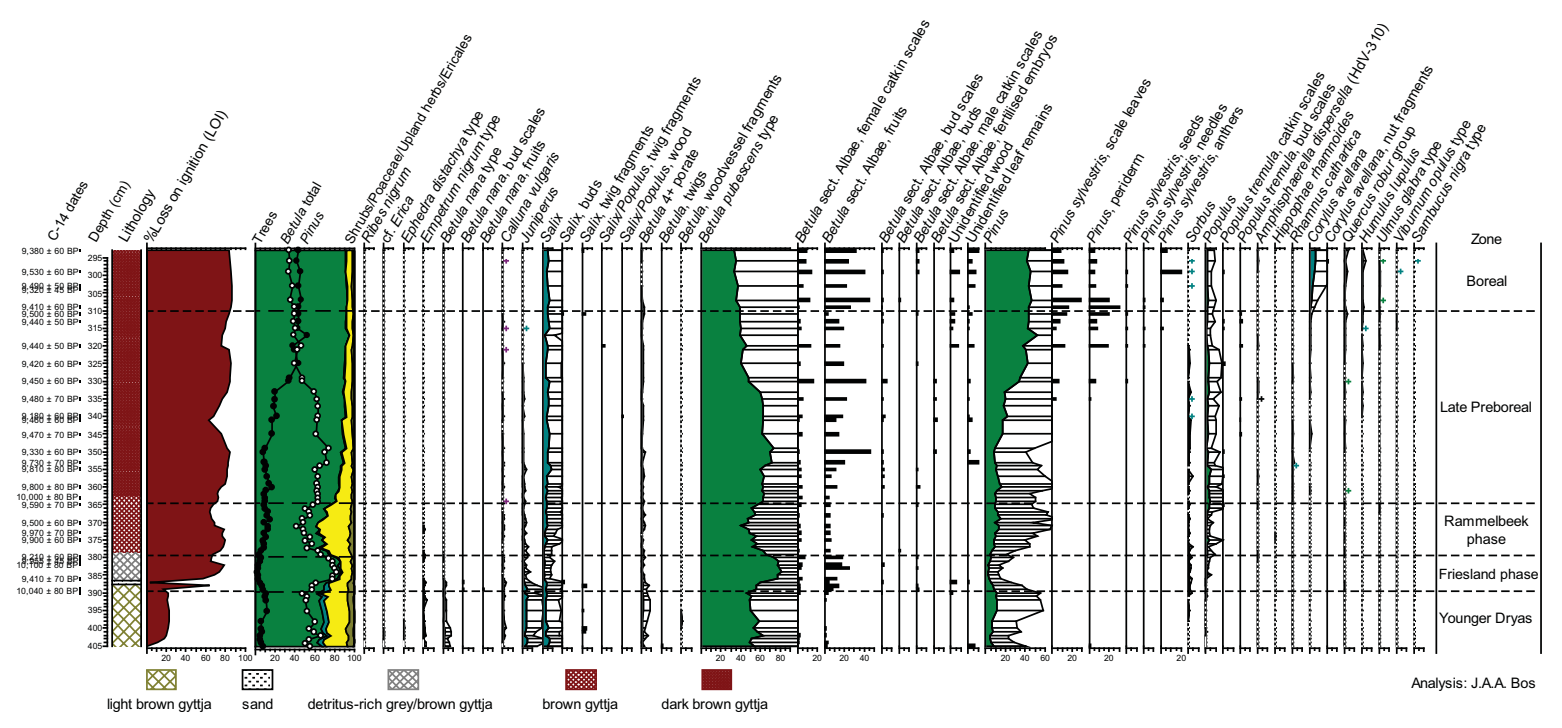

(a)

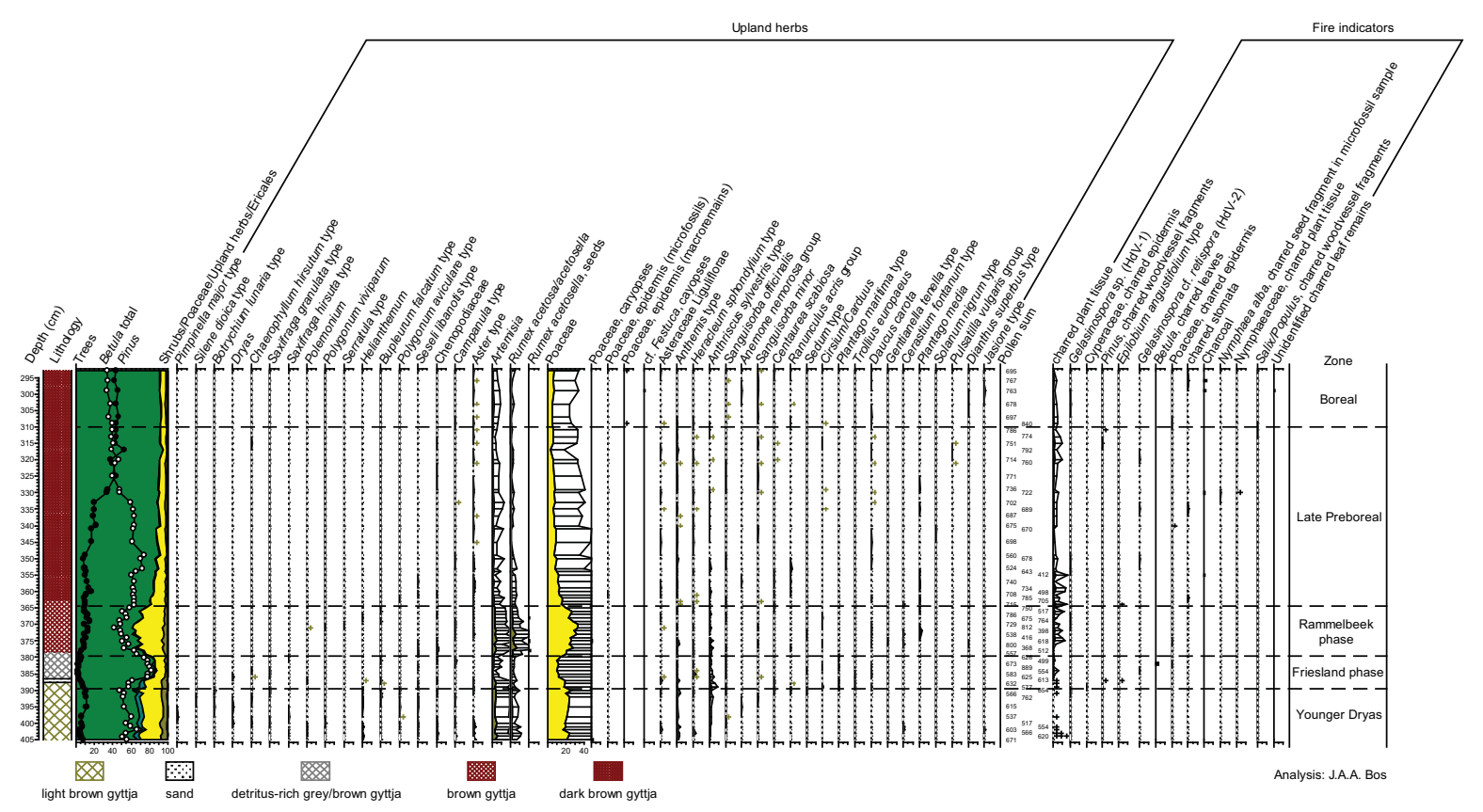

(b)

Fig. 2. Combined microfossil and macroremain diagram of the Haelen record. Microfossils (pollen, spores etc.) are shown as curves (\%), macroremains (fruits, seeds, wood, etc.) as histograms giving total amounts. Exaggeration of microfossil curves $5 \times$. (a) Trees, shrubs and Ericales; (b) upland herbs and fire indicators; (c) reed swamp and damp woodland soil taxa, HdV-types and coprophilous taxa; (d) aquatic botanical and zoological taxa; (e) reworked taxa.

area of the Netherlands (Hoek, 1997b; Bos et al., 2007). Grasslands and tall-herb vegetation were probably abundant on the Meuse River floodplain near Haelen and on the slopes of the nearby terraces with, apart from various Poaceae (grasses), also herbs such as Sanguisorba officinalis (great burnet), Polemonium caeruleum (Jacob's ladder), Helianthemum (rock rose), Saxifraga granulata (meadow saxifrage), Campanula (bellflower) and various Asteraceae (composites), Caryophyllaceae (carnations) and Apiaceae. Amongst the Apiaceae, various taxa were recorded, such as Anthriscus sylvestris (cow's parsley), Pimpinella major-type (greater burnet-saxifrage), Bupleurum falcatum (sickle hare's ear) and Heracleum sphondylium (hogweed). Many of these taxa prefer lime-rich soils.

On the higher terraces the vegetation was rather scarce. Here probably some shrubs of juniper and willow, Poaceae and herbaceous vegetation with Botrychium, Chenopodiaceae (goosefoots), Asteraceae and Caryophyllaceae were present (cf. Bos et al., 2006). Saxifraga spp. (saxifrages), Polygonum viviparum 


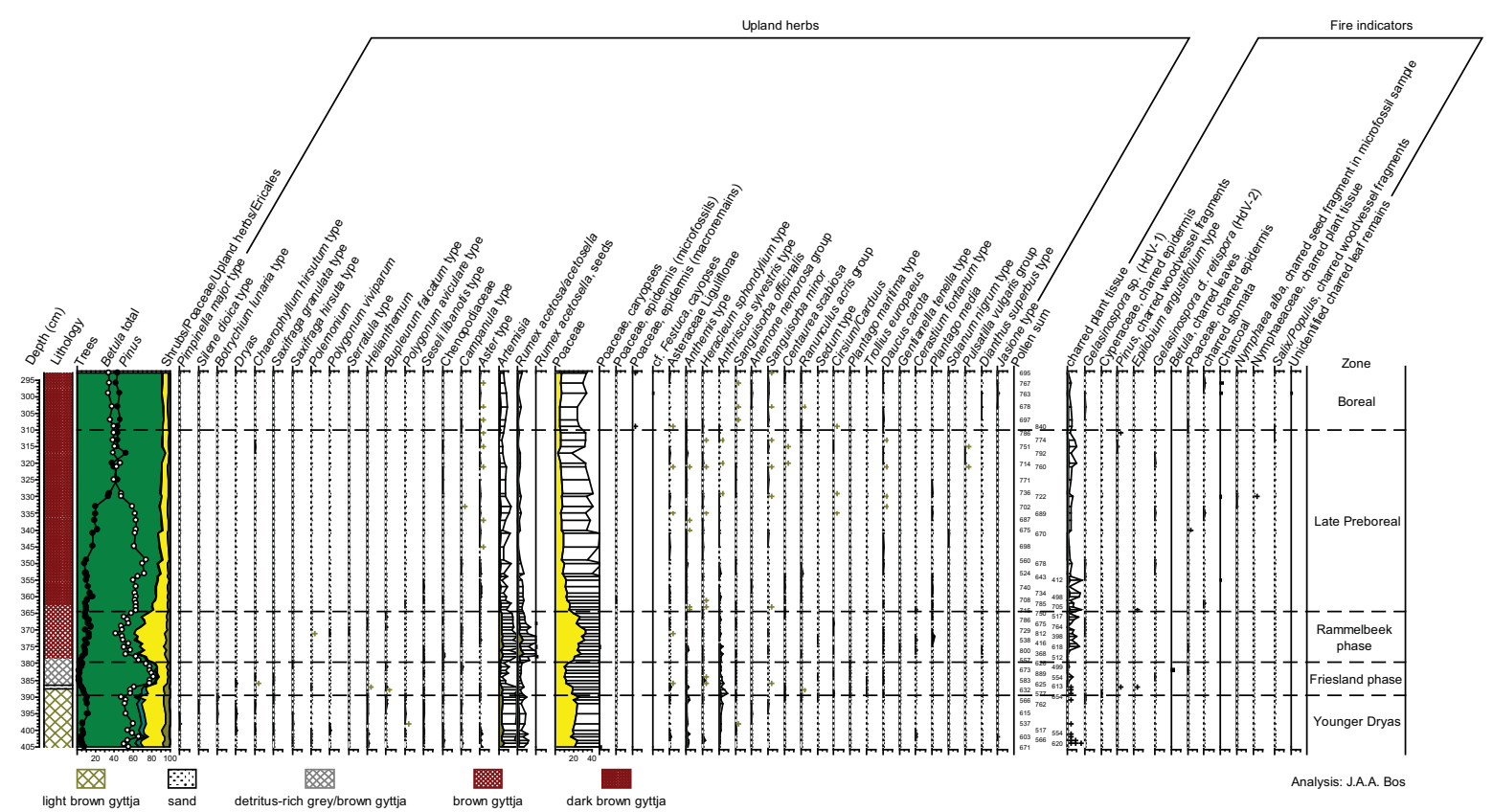

(c)

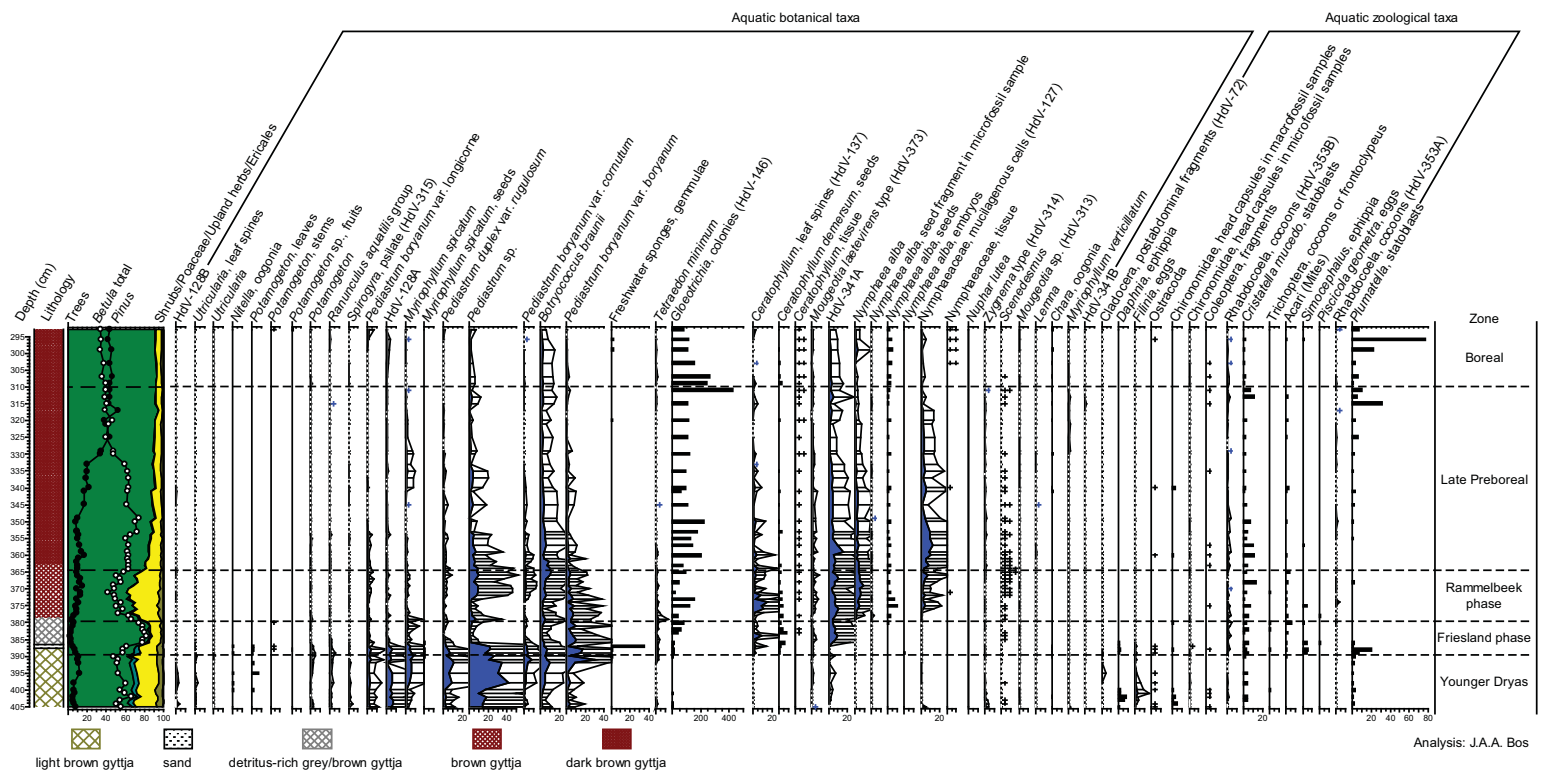

(d)

Fig. 2. Continued.

(alpine bistort) and Dryas octopetala (mountain avens) were probably also found on these open, often calcareous-rich soils.

On the river floodplains, birch woodlands were present in the wet to moist zones around depressions and (oxbow) lakes. In the understorey of these forests and on forest edges, Chaerophyllum temulum (rough chervil), Anthriscus sylvestris, Anemone nemorosa (wood anemone), Poaceae and some Polypodiaceae (ferns) could be found, while taxa such as Polygonum aviculare (pigweed), Rumex acetosella (sheep's sorrel) and Artemisia (mugwort) indicate the presence of trampled areas and open, disturbed grounds.
Records of ascospores of coprophilous fungi such as Sordariatype and Apiosordaria verruculosa (HdV-55A and HdV-169; van Geel et al., 2003; van Geel \& Aptoot, 2006; Fig. 2c) may suggest that large herbivores were present in the area and used the lakeshores as a watering place.

Preboreal: Friesland Phase At Haelen, the start of the Holocene was dated around 11,520 cal BP (Table 2). This transition is characterised by abrupt warming and an increase in precipitation. Based on changes in the forest composition (AP) and herbaceous vegetation (NAP), the Preboreal biozone in the 


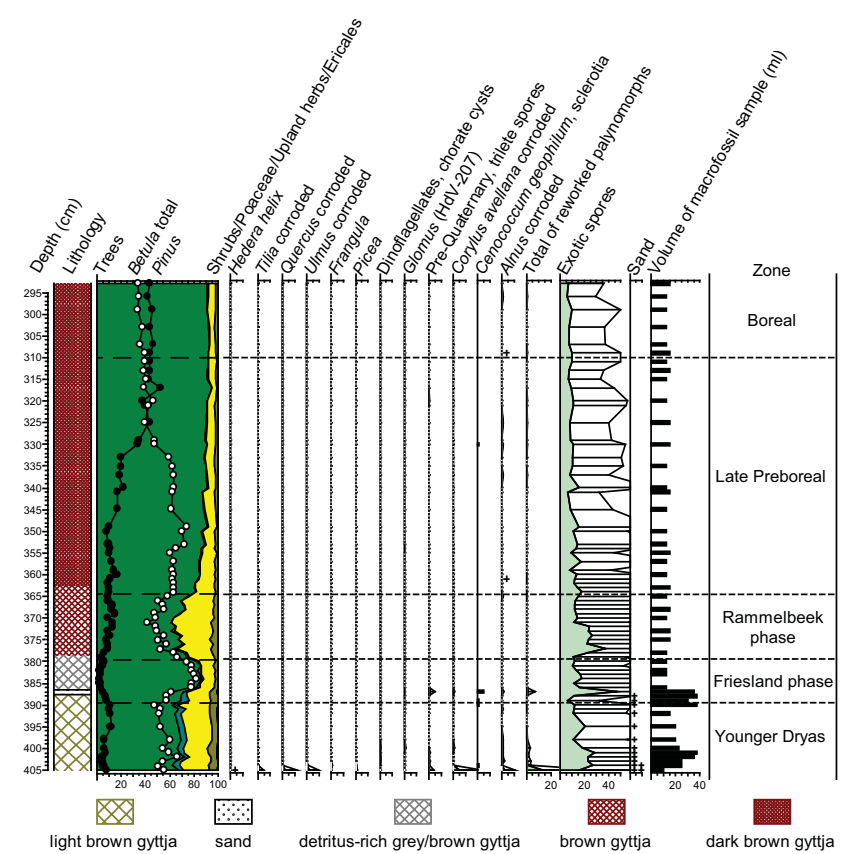

(e)

Fig. 2. Continued.

Netherlands is subdivided into the Friesland Phase, the Rammelbeek Phase and the Late Preboreal (e.g. Behre 1966, 1978; Wijmstra \& de Vin, 1971; van Geel et al., 1981). Also in the Haelen sequence this subdivision of the Preboreal is clearly recognisable (Fig. 2).

The Friesland Phase (Behre, 1966) was a period of rising mean summer and winter temperatures (Renssen \& Isarin, 2001), characterised in the Netherlands by a strong expansion of woodlands with birch, i.e. mainly Betula pubescens (van Geel et al.,
Table 2. WMD dated zone boundaries (in cal BP) in the Haelen record.

\begin{tabular}{ll}
\hline & Age cal BP \\
\hline Late Preboreal/Boreal transition & $10708 \pm 5$ \\
Pine expansion & $11170 \pm 5$ \\
Rammelbeek Phase/Late Preboreal transition & $11266 \pm 5$ \\
Friesland Phase/Rammelbeek Phase transition & $11420 \pm 5$ \\
Late-glacial/Holocene transition & $11522 \pm 10$ \\
\hline
\end{tabular}

1981; Bos et al., 2005a, 2007). Around the Haelen site, birch trees were forming woodlands. In the river valleys of the Meuse and Scheldt (Bos et al., 2007) the expansion of birch is accompanied by an increase in Populus (poplar) (Figs 2a and 3). During the Friesland Phase, woodlands with birch and poplar replaced the grasslands on the floodplains of the Meuse River and on the slopes of the river terraces. Also Sorbus, probably $S$. aucuparia (mountain ash), was growing in these forests. Grasses, heather, hogweed, rough chervil and cow parsley were forming the understorey or could be found along forest edges.

The open herbaceous vegetation with dwarf shrubs and Ericales that was so typical for the Younger Dryas largely disappeared during the Friesland Phase. On the nearby sandy and gravelly terraces and slopes, some open herbaceous vegetation, grasses and juniper shrubs remained present, while on sandy, nutrient-rich beaches, along the river, Plantago maritima type (likely $P$. arenaria, branched plantain) was probably growing.

Some pine trees could be found on the higher terraces. Pine had suffered considerably from the colder, wetter climate during the Younger Dryas, but finds of Pinus macroremains at several sites indicate that the species was still present at

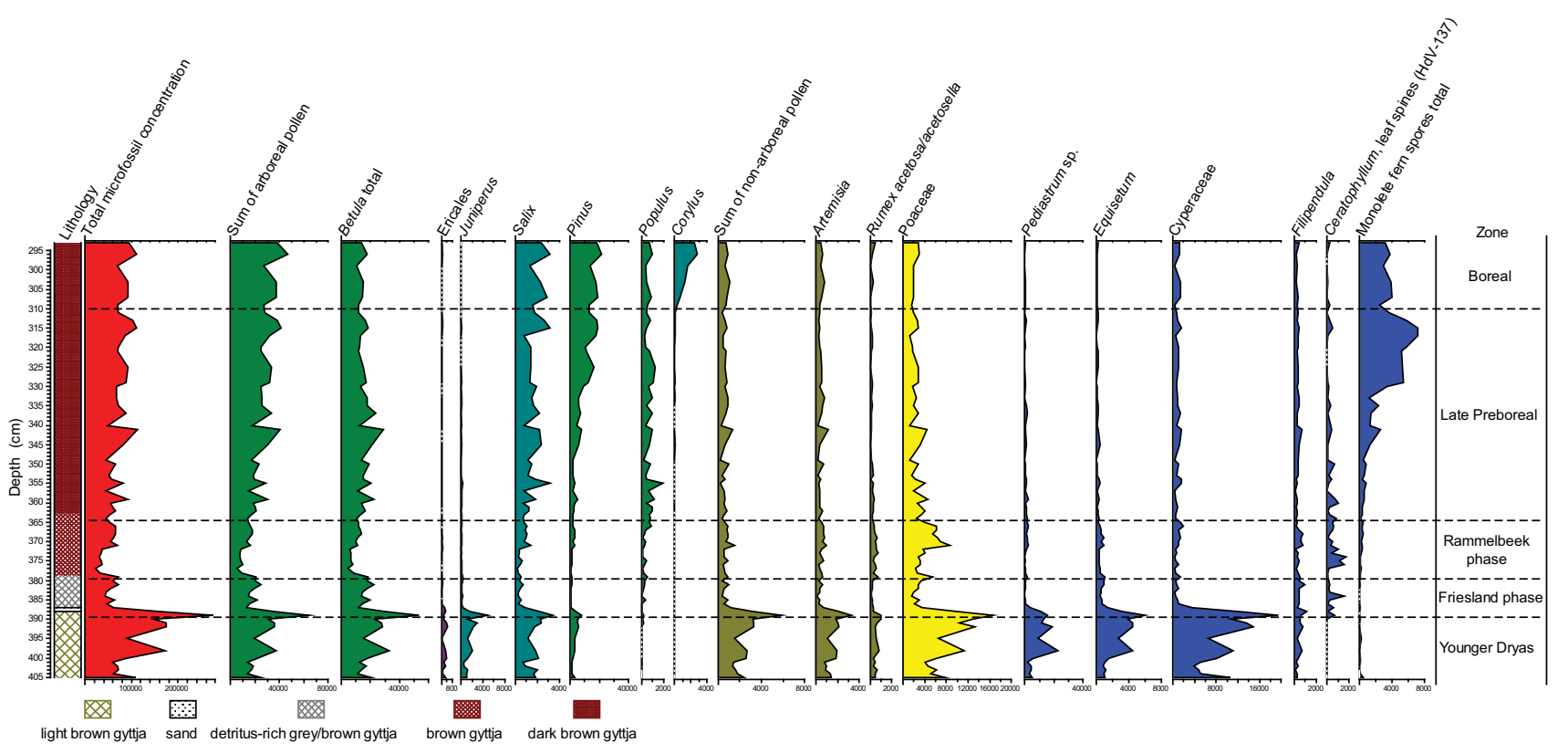

Fig. 3. Concentration diagram of the Haelen record. 
sheltered locations in the Netherlands during the early Preboreal (Bos et al., 2007).

On the slopes of the terraces grasslands with Daucus carota (wild carrot), Centaurea scabiosa (greater knapweed), Sanguisorba minor (salad burnet), cow parsley and Ranunculus acris group (buttercup) were present. Trollius europaeus (globeflower) was probably growing in damp meadows, and in grasslands less rich in nutrients Ophioglossum vulgatum (adder'stongue) appeared. Although Trollius is poisonous for large herbivores, some of the plants mentioned above suggest that grazing of the grasslands was taking place. Furthermore, records of Polygonum aviculare, sheep's sorrel and mugwort suggest the presence of tramped areas or disturbed soils, but no coprophilous fungi were recorded. Trampling and disturbance of soils may also have been related to the presence of Mesolithic people. During the Mesolithic, the principal means of subsistence were hunting, fishing and gathering, all activities that had a small, local impact on the surrounding vegetation (e.g. Bos \& Urz, 2003; Bos et al., 2005b; Woelders et al., 2015). However, the presence of Mesolithic people may also have been reflected in the occurrence of fire indicators. During the Friesland Phase, large numbers of fire indicators (i.e. charred plant tissue, ascospores of Gelasinospora sp. and G. cf. retispora, charred epidermis of Poaceae and Cyperaceae, remains of charred leaves of birch and pollen of Rumex acetosella and Epilobium angustifolium, fireweed; Fig. 2b) were found, indicating the occurrence of fires in the shore/forest vegetation and possible presence of fire places of Mesolithic people. Both Epilobium angustifolium and Rumex acetosella can be pioneers in localities where the (forest) vegetation is burned or cut down (van der Hammen, 1951; van Geel et al., 1981; www.soortenbank.nl). However, there is no direct archaeological evidence for the presence of Mesolithic people in the area during the Friesland Phase.

Preboreal: Rammelbeek Phase The Rammelbeek Phase (Behre 1966, 1978; Wijmstra \& de Vin, 1971; van der Plicht et al., 2004) started in the Haelen sequence around 11,420 cal BP (Table 2). During this phase, the pollen diagram shows a maximum in the Poaceae percentages and a minimum in the values of birch pollen and macroremains (Figs 2 and 3). This suggests that forest expansion was temporarily interrupted and grasses dominated the regional vegetation. Also other taxa indicating open grounds or short grasslands, such as Artemisia, Rumex acetosella (also seeds were recorded), Polygonum viviparum, Helianthemum and Dianthus (pink), (re)appear or show higher values again.

On the river floodplain the birch woodlands diminished and were largely replaced by grassland vegetation. Also, on the slopes of the nearby terraces, grasslands appeared. In these grasslands many herbaceous species were present, such as Sanguisorba officinalis and S. minor, Polemonium, Helianthemum, Ranunculus, Campanula, Anthriscus sylvestris, Bupleurum falcatum, Gentianella (dwarf gentian), Plantago media (hoary plan- tain) and various Asteraceae and Caryophyllaceae. On the sandy and gravelly terraces open herbaceous vegetation, some juniper and Hippophae rhamnoides (sea-buckthorn) shrubs and pines remained present.

The Rammelbeek Phase was a dry, continental phase with relatively warm summers and cold winters (van Geel \& Kolstrup, 1978; van Geel et al., 1981). Given the drier and warmer climate, fires might have been expected to occur more regularly. However, only few fire indicators were recorded, far fewer than during the previous Friesland Phase. This may suggest that many of the fires during the earlier Friesland Phase were indeed related to the presence of Mesolithic people, who occupied the area only briefly and may not have left archaeological traces.

Preboreal: Late Preboreal The Rammelbeek Phase was followed at the Haelen site around 11,270 cal BP by the Late Preboreal (Table 2). In the Netherlands the start of the Late Preboreal was characterised by a change to a wetter climate (van der Plicht et al., 2004; Bos et al., 2007). At Haelen, the Late Preboreal is a phase during which birch woodlands expanded again on the river floodplains and slopes of the nearby terraces. Also, poplar became more abundant in these woodlands (Figs $2 a$ and 3 ). The local presence of poplar is indicated not only by records of macrofossils (both catkin and bud scales), but also by numerous finds of ascospores of the parasitic fungus Amphisphaerella dispersella (Type HdV-310; van Geel \& Aptroot, 2006). Macrofossils of birch and poplar suggest that birch and poplar swamp forests were locally present around the Haelen residual channel. Furthermore, shrubs such as Sorbus aucuparia, Rhamnus cathartica (buckthorn) and Viburnum opulus (guilder rose) and herbs like cow parsley, rough chervil, wood anemone and grasses were growing in the understorey or at the edges of these forests, while Humulus lupulus (hop) was climbing in the trees.

Pine expanded on the higher sandy and gravelly terraces around the Haelen site during the later part of the Late Preboreal, around 11,170 cal BP (Table 2; Figs 2a and 3). In the diagram pine pollen becomes dominant over birch during the Late Preboreal, but pine values remain only slightly higher than birch values. The high pollen values and presence of pine macroremains (i.e. periderm, scale leaves, seeds, needles and anthers; Fig. 2a) suggest that pine was growing close to the sampling site, probably on a higher terrace to the west. Due to the prevailing NW winds, pine pollen and macrofossils could spread easily into the Haelen residual channel.

As both pine and birch forests became more abundant in the landscape around Haelen, herbaceous communities slightly decreased. On the slopes of the river terraces, however, grass and tall-herb vegetation with Daucus carota, Centaurea scabiosa, Sanguisorba minor, Campanula, Heracleum sphondylium, Anthriscus sylvestris, Ranunculus, Plantago media and various Asteraceae remained present. At the end of the Late Preboreal some taxa such as Solanum nigrum (black nightshade), Pulsatilla vulgaris (pasqueflower) and Chenopodiaceae (re)appear. 
The presence of Rumex acetosella and Artemisia indicates that some disturbed grounds and dry and open sandy soils, poor in nutrients, were present. These may be related to trampling or disturbances by animals or by early Mesolithic people. Coprophilous fungi nevertheless were absent from the record, and there is no archaeological evidence for the presence of Mesolithic people in the area during the Late Preboreal. The presence of numerous fire indicators, however, may suggest otherwise. During the Late Preboreal quite a few fire indicators were recorded (Fig. 2b). In the lower part of the Late Preboreal charred plant tissue, pollen of fireweed, Gelasinospora ascospores and charred epidermis of grasses were found. In the upper part of the Late Preboreal some charred remains of pine and poplar or willow wood were present. A rather exceptional find was a charred seed of Nymphaea alba (white water lily) and charred plant tissue of Nymphaeaceae. This may suggest that natural or man-made fires or fire places occurred during the Late Preboreal. The presence of charred remains of water lily may be explained by the fact that seeds and tubers of water lily were consumed and probably roasted during the Mesolithic (Out, 2008).

Boreal The onset of the Boreal was characterised by the immigration of Corylus (hazel) and dates around 10,710 cal BP (Table 2; Figs 2a and 3). Corylus is shortly followed by Quercus (oak) and Ulmus (elm). Later also Tilia (lime) appears in the forests around Haelen (Verbruggen et al., 2003). In this period, dense forests started to expand in the middle Meuse River valley with thermophilous deciduous shrubs and trees such as hazel, oak, elm and lime. Initially, hazel shrub developed in and at the edges of open forests on the river floodplain and on the slopes of the terraces. Later in the Boreal period, oak and elm spread in these forests. Sambucus nigra (black elder), Melampyrum (cow wheat) and grasses were growing in the understorey of oak forests. Birch and poplar forests were present on the wetter parts of the floodplains, and around the Haelen residual channel they probably formed a zone behind the shoreline or were partly intermixed with the shore vegetation. In the undergrowth of these swamp forests, Scirpus sylvaticus (wood club rush), Lythrum salicaria (purple loosestrife), Filipendula ulmaria (meadow sweet), Valeriana officinalis (common valerian), Urtica dioica (common nettle), Solanum dulcamara (bittersweet), Hippuris vulgaris (mare's-tail), Lycopus europaeus (gypsywort) and ferns could be found. Tilia expanded slightly later during the Boreal on the nearby higher terraces.

As the quantity of forests increased, grasslands became less abundant. However, some herbaceous vegetation remained present, with grasses such as Festuca (fescue), and with Daucus carota, Centaurea scabiosa, Sanguisorba minor, Campanula, Anthriscus sylvestris, Ranunculus and various Asteraceae. Also Rumex acetosella, Artemisia, Dianthus and Jasione (sheep's bit scabious) suggest that some open, disturbed soils remained present on the higher terraces.
Finds of charred plant tissue, charred grass epidermis, charred wood and leaf remains indicate the occurrence of (natural or man-made) fires during the early Boreal. The Haelen pollen diagram presented here ends around 10,530 cal BP. The first archaeological evidence for the presence of early Mesolithic people near Haelen dates around 10,250-10,150 cal BP (Bats et al., 2010). However, early Mesolithic people may have been present earlier, leaving no archaeological traces, or such traces were simply not recovered yet.

\section{Vegetation succession in the residual channel}

During the last part of the Younger Dryas, the former channel near Haelen was abandoned and an oxbow lake was formed. Aquatic plant communities developed with predominantly submerged taxa such as Utricularia (bladderwort) and Myriophyllum spicatum (spiked water milfoil), Ranunculus aquatilisgroup (water crowfoot), Potamogeton (pondweed), Nitella sp. (stoneworts) and many different algae (e.g. Botryococcus braunii, Pediastrum spp., Mougeotia spp., Spirogyra, Zygnema, Scenedesmus, Tetraedon minimum and HdV-128) were abundant. The presence of Myriophyllum spicatum may suggest that the water depth in the deepest parts of the channel would have been up to $5 \mathrm{~m}$ (cf. Hannon \& Gaillard, 1997).

In the former channel also a rich water fauna was present with waterfleas (Daphnia and other Cladocera), mites (Acari), non-parasitic flatworms (Rhabdocoela), Caddis flies (Trichoptera), bryozoa (Cristatella mucedo), seed shrimps (0stracoda), rotifers (Filinia), non-biting midges (Chironomidae) and beetles (Coleoptera). The aquatic flora and fauna suggest that the water in the residual channel was calcareous and nutrient-rich and probably was (temporarily) still flowing slowly. A light brown gyttja was deposited in the residual channel, in which the organic component must have been rather low, as LOI values of c. $22 \%$ are recorded.

In and along the shallow water of the shores a vegetation type was present with willow, Carex spp. (sedges, also indicated by Clasterosporium caricinum or HdV-126, which uses Carex as a host plant) and herbs such as Valeriana officinalis, horsetail (Equisetum), meadow-rue (Thalictrum), Filipendula, Urtica dioica, burreed (Sparganium), bulrush (Typha spp.), bogbean (Menyanthes trifoliata), crucifers (Sinapis and Hornungia-type) and Apiaceae (e.g. Oenanthe and/or Cicuta, Peucedanum). Many of these taxa (e.g. Thalictrum, Filipendula, Valeriana officinalis and Carex spp.) may also have grown in grasslands on the wetter parts of the river floodplains. On peaty patches peat moss (Sphagnum) could be found.

At the start of the Friesland Phase the LOI values show a strong increase to a maximum of almost $80 \%$, indicating a change to more organic-rich deposits (i.e. detritus-rich grey/brown gyttja) as a result of an increase in biological productivity. The increase is followed by a major drop in the values 
at $387 \mathrm{~cm}$, where a sandy layer is present. After this drop, the LOI values return to earlier levels.

Amongst the aquatics, most-demanding taxa remain present that were present earlier, but many (especially Myriophyllum spicatum and various algae) show much lower values. New taxa such as rigid hornwort (Ceratophyllum demersum), cyanobacteria (Gloeotrichia-type) and freshwater sponges appear, while some algae such as Pediastrum boryanum var. boryanum and Tetraedon minimum show maximal values. The aquatic taxa indicate that during the early Preboreal a gradual increase in water level occurred. Higher lake water levels between 11,450 and 11,400 cal BP have also been reported from elsewhere in the Netherlands and west-central Europe (Hoek \& Bohncke, 2002; Magny et al., 2007), suggesting that the increase in temperature at the start of the Holocene coincided with an increase in precipitation. The presence of the above-mentioned taxa furthermore suggests that the water in the residual channel was nutrient-rich and may have been streaming from time to time. Cyanobacteria of the Gloeotrichia-type are often among the first colonisers in a new lake, and by fixing nitrogen they can open local conditions for other aquatic plants (van Geel et al., 1989). Their abundance, however, may also have been a reflection of the relatively warmer climatic conditions at the start of the Holocene (van Geel et al., 1989).

Along the shores vegetation was present with less willow and sedges than during the Younger Dryas, but with more different herbs (e.g. Filipendula, Urtica dioica, Menyanthes trifoliata, Equisetum, Solanum dulcamara, Hippuris vulgaris, Lycopus europaeus and Comarum palustris (marsh cinquefoil)). Taxa such as Menyanthes trifoliata, Hippuris vulgaris and Lycopus europaeus are typical for seepage situations (Weeda et al., 1987, 1988). Their presence may suggest that seepage occurred during the Friesland Phase, which is probably related to the high terrace directly west of the Haelen residual channel.

During the Rammelbeek Phase, aquatics with floating leaves, such as white water lily, became abundant in the aquatic vegetation of the residual channel, which may suggest that the water in the residual had become stagnant. The white water lily vegetation remained present far into the Late Preboreal. Brown gyttja was deposited during the Rammelbeek Phase, which became more dark brown and peaty at the transition to the Late Preboreal. LOI values drop from c. $76 \%$ to c. $66 \%$ during the second part of the Rammelbeek Phase, which is related to a higher minerogenic content. This may have had several causes, namely a decrease in biological productivity, a lowering of the water table and/or an increase in eolian activity due to a less forested, more open landscape with soils not completely covered by vegetation. At Haelen, shifts in the aquatic and telmatic taxa suggest that a lowering of the water table occurred. However, upland surface erosion due to the more open landscape may also have caused an increased influx of minerogenic particles.

The composition of the shore vegetation remains more or less the same as during the Friesland Phase. New taxa such as Phrag- mites australis (reed) and Caltha palustris (marsh marigold) are occasionally recorded and suggest that these species also became a component of the shore vegetation.

From the Late Preboreal onwards, a genuine reed swamp with Thelypteris palustris (marsh ferns) and tall plants such as Phragmites australis, Sparganium, Typha angustifolia and T. latifolia formed along the shores of the residual channel. At the shores and in the swamp forests with birch and poplar also various herbs (e.g. Lysimachia (loosestrife), Solanum dulcamara, Filipendula, Thalictrum, Equisetum, Valeriana officinalis, Urtica dioica, Hydrocotyle vulgaris (marsh pennywort) and Apiaceae) were growing. Dark brown gyttja was deposited in the residual channel, which is also reflected in high LOI values of $c$. $80 \%$ on average. During the Late Preboreal, only a few minor oscillations are recorded in the LOI values.

During the later part of the Late Preboreal, Lemna (duckweed), Myriophyllum verticillatum (whorl-leaf watermilfoil) and Chara (stone worts) (re)appear, which suggests slightly higher water tables. It also indicates that due to seepage the water was slightly calcareous and rich in nutrients during the later part of the Late Preboreal. The (re)appearance of Scirpus sylvaticus and Lycopus europaeus suggests that seepage of groundwater probably continued during the Boreal. During the early Boreal, aquatic vegetation of species with floating leaves (i.e. Nymphaea alba and Nuphar lutea (yellow water lily) and Potamogeton) and plants with submerged leaves (e.g. Myriophyllum verticillatum and Ceratophyllum demersum) remained present in the residual channel. White water lilies were probably present at more shallow, sheltered locations near the shores, while submerged Myriophyllum verticillatum and Ceratophyllum demersum were more abundant in the deeper parts of the residual channel. The abundance of Nymphaea alba indicates that the water at the sampling site was rather shallow, probably 1-1.5 m deep (cf. Hannon \& Gaillard, 1997). The abundance of bryozoans (Plumatella cf. repens) may suggest an increase of shade around the residual channel caused by the surrounding forest vegetation. During this period the shores were fringed by reed swamps in which Lythrum salicaria and Alisma plantagoaquatica (common water plantain) were also growing. On peaty spots along the shores Viola palustris (marsh violet) and Sphagnum were also found.

\section{Discussion}

\section{Comparison with other records in the middle Meuse River valley}

The trends in the Haelen pollen diagram are highly comparable with those in the pollen diagram of the slightly more easternlocated Boukoul site (Buijs, 2013). The Boukoul pollen diagram is less detailed and lacks radiocarbon dates. Other pollen diagrams representing this period in the middle Meuse valley are 
present from locations slightly further south, such as Korbusch (S.J.P. Bohncke, unpub. data), Kingbeekdal (Bohncke \& Hoek, 2007) and Dukkelaar (0tten, 2013), and further north, such as Hout-Baarlo (Blokker, 2013) and Blerick-Koelbroek (Bos, 1992). Furthermore, a detailed pollen diagram is present from the Tungelroyse Beek valley, a tributary of the river Meuse, located in the southern coversand region of the Netherlands (Woelders et al., 2015).

The meanders at Dukkelaar, Kingbeekdal and Korbusch in the lower part of the middle Meuse River valley were all abandoned during the Younger Dryas when the Maas shifted eastwards (0tten, 2013) and probably all represent the same meander generation. The meanders of Haelen in the west and Boukoul in the east are situated opposite each other and may also be of the same meander generation. From the more upstream part of the middle Meuse valley only the meander near Hout-Baarlo is known as being abandoned during the Younger Dryas. All Younger Dryas records show that the middle Meuse River valley during this period was characterised by an open landscape with heliophilous herbs and dwarf shrubs, while grasslands were also rather abundant. This suggests that the vegetation development during the Younger Dryas at Haelen is representative for the middle Meuse valley. Higher grass values were also recorded in the Scheldt River area and can thus be regarded as typical for the river region during the Younger Dryas period in the Netherlands (Bos et al., 2007). For example, at Tungelroy (Woelders et al., 2015), a river setting within the eastern coversand region, grass vegetation was much less abundant during this period.

The Friesland Phase can easily be recognised in all records by a strong increase in birch values. The grass-dominated Rammelbeek Phase varies and may be easily recognisable (i.e. HoutBaarlo, Boukoul, Korbusch and Kingbeekdal), recognisable only with rather low grass values (i.e. Tungelroy) or not recognisable at all (i.e. Dukkelaar). In Hout-Baarlo the grass maximum is very high, which may be a reflection of the local vegetation around the channel. In the pollen diagrams of the northern Meuse valley (Hoek et al., 2016) the Rammelbeek Phase cannot always be distinguished. This may be related to the lower groundwater levels that occurred during the Rammelbeek Phase in the Netherlands, but it may also be connected with river incision during this period (Hoek, 1997a; Hoek \& Bohncke, 2002; Bohncke \& Hoek, 2007; Bos et al., 2007). The start of the Rammelbeek Phase is coeval with the coldest part of the Preboreal oscillation (PB0; Björck et al., 1996, 1997) as observed in the $\delta^{18} 0$ record of the Greenland ice-core records (e.g. Dansgaard et al., 1993; Johnsen et al., 1997; NGRIP members, 2004; Rasmussen et al., 2006, 2007, 2013; sensu Bos et al., 2007).

During the Late Preboreal, birch values increase again in all records of the middle Meuse River valley. In the records downstream (Kingbeekdal, Korbusch and Dukkelaar) pine is already high or dominant from the start of the Late Preboreal onwards.
In the more central and northern sites of the middle Meuse valley (Haelen, Boukoul, Hout-Baarlo and Tungelroy), pine increases and becomes dominant during the later part of the Late Preboreal. The increase in pine thus occurs earlier in the records downstream. Although pine was already locally present at sheltered locations, this may suggest that pine was using the terraces of the Meuse River valley as a (re)immigration route, similar to the river Rhine during the Late-glacial (sensu Hoek, 1997a; Bos, 2001). Despite numerous macrofossils, the pine pollen values in the Haelen record, however, remain rather low and pine and birch remain subdominant. This was probably caused by an overrepresentation of birch that was growing in the local vegetation around the Haelen residual channel.

The early Boreal can be recognised in all these palynological studies by a strong increase in hazel, followed by a increase in oak, elm and later also in lime. In some records (Hout-Baarlo, Dukkelaar and Tungelroy), lime does not appear earlier than the Atlantic period.

The Haelen pollen zones can also be compared with the radiocarbon-dated Pollen Assemblage Zones (PAZ) established for the Late-glacial and Early Holocene of the Netherlands (Hoek, 1997a). These PAZ are also applicable on the pollen diagrams of the northern part of the Meuse River valley (=Sand Maas) (Hoek et al., 2016) and are based on some 35 pollen diagrams and $>50$ radiocarbon dates. A highly detailed and well-dated reconstruction of the vegetation and terrace formation during the Late-glacial and Early Holocene was made (Hoek et al., 2016). Pollen zone PAZ 4 (Betula-Poaceae PAZ) can be linked with the Friesland and Rammelbeek Phases, while PAZ 5 (Pinus PAZ) reflects the Late Preboreal. Further north of Haelen, there are also the archaeological sites of Lomm and Well-Aijen (F.S. Zuidhoff \& J.A.A. Bos, in prep.; Bos \& Zuidhoff, 2015). The residual channels discussed in these archaeological studies, however, start accumulating during the early Boreal, which means that there is only a small overlap between those records and Haelen. The records of Haelen, Well-Aijen and Lomm all show a strong increase in hazel during the early Boreal, followed by an increase in oak, elm and later also lime. This suggests that hazel occurred almost simultaneously at all these sites.

\section{Archaeology}

Finds of archaeological remains indicate that people were present in the Haelen area from the Boreal onwards (Bats et al., 2010; Scheurs, 2013). Flint artefacts and AMS ${ }^{14} \mathrm{C}$ dates on fragments of hazelnut shells date the first habitation phase near Haelen around 10,250-10,150 cal BP (i.e. 8300-8200 cal BC; Bats et al., 2010). The concentration of flint artefacts was probably linked to a short-lived habitation phase of huntergatherers (Bats et al., 2010). The Haelen pollen diagram shows that the early Mesolithic people during the Boreal were living in a forested landscape. On the lower parts of the river floodplains 
and around former channels birch forest was present, while hazel shrubs and deciduous mixed forests expanded on the higher parts of the floodplains and edges of terraces. On the sandy Meuse River terraces, pine woodlands remained present as a relict from the Late-glacial. Along the residual channel tall reed swamps had developed, which may have restricted the view to open water with aquatic vegetation in the residual channel.

In the Haelen record there are indications that people temporarily inhabited the area during the Preboreal. During the Friesland Phase, Late Preboreal and early Boreal, a large number of fire indicators was recorded, indicating the occurrence of fires in the shore/forest vegetation and possible presence of fire places of Mesolithic people. Also herbs such as Epilobium angustifolium, Rumex acetosella, Artemisia and Polygonum aviculare may indicate the presence of trampled areas, disturbed grounds or localities where the (forest) vegetation was burned or cut down. Furthermore, the presence of a charred seed of white water lily and presence of charred plant tissue of Nymphaeaceae suggests that seeds and tubers of these plants were consumed. The tubers of white water lily were probably used as a root vegetable during the Mesolithic (Out, 2009). The charred plant tissue suggests that tubers were roasted. Roots and tubers likely formed the most abundant and readily available source of starch in the increasingly forested environment of Mesolithic temperate Europe (Kubiak-Martens, 2015). Other species that may have been consumed as starchy food during the early Mesolithic are the inner bark tissue of birch and pine and tubers of horsetail species. In the vegetation around Haelen furthermore a wide range of edible plants was present for gathering (based on Renfrew 1973; Körber-Gröhne 1987; Oberdorfer, 1990; Kubiak-Martens 1996, 1999, 2015; Out, 2009); for example, knotgrass (Polygonum), dock (Rumex), common nettle and goosefoots (Chenopodiaceae) were available as green vegetables. The latter could also have been used for their edible seeds. Tubers of wild carrot, fruits of mountain ash and rhizomes of hop, knotgrass, bulrush and ferns may also have been used as vegetables, and Filipendula, Valeriana officinalis, Solanum dulcamara, Menyanthes trifioliata, Nymphaea alba and Polygonum aviculare as medicinal plants. During the Boreal also, acorns and hazelnuts, fruits of guilder rose and black elder and seeds and tubers of yellow water lily were available.

Despite the botanical signals that early Mesolithic people may have occupied the Haelen area during the Friesland Phase, Late Preboreal and early Boreal, no archaeological evidence for their presence was found before 10,250-10,150 cal BP (see Bats et al., 2010). Early Mesolithic people may only have occupied the area briefly, leaving no archaeological traces, or such traces may not yet have been recovered. However, archaeological evidencefrom other sites in the Meuse and the more easterly Roer River valley (e.g. Verhart, 2008; ter Wal \& Tebbens, 2012; Bouma \& Müller, 2014) suggests that groups of early Mesolithic huntergatherers-fishers were already present in this area during the Preboreal.

\section{Conclusions}

(1) The detailed multi-proxy, high-resolution analyses (including microfossils, macroremains, LOI measurements and AMS ${ }^{14} \mathrm{C}$ wiggle-match dating) of the Haelen site provide valuable and detailed information about the vegetation and climatic history of the middle Meuse River valley during the Early Holocene.

(2) The Haelen record, covering the Late-glacial/Holocene transition and Preboreal, reflects a $>1000$-year period during which major climate changes occurred on a northern Atlantic scale. The Late-glacial/Early Holocene transition is characterised by a period of abrupt warming and expansion of birch forests, the Friesland Phase. This is followed by two short climatic oscillations, the dry, continental Rammelbeek Phase with open grassland vegetation and the wetter Late Preboreal during which birch forest and later pine forest expanded. These oscillations could be recognised in the detailed regional pollen diagram of the Haelen sequence.

(3) The Haelen record furthermore compares well with other pollen diagrams of the northern and middle Meuse River valley. All records show a strong increase in the pollen representation of birch during the Friesland Phase, but in some records the Rammelbeek Phase is not recognisable or is absent due to a hiatus. During the Late Preboreal, the pine values increase. This occurs earlier in the records of the downstream part of the middle Meuse River valley and may suggest that the terraces of the Meuse River valley formed a migration route for pine.

(4) The microfossil record of the Haelen site suggests that the landscape was already densely forested when Mesolithic people arrived in the area c. 10,250-10,150 cal BP. The Preboreal part of the Haelen record shows some indications that people already temporarily inhabited the area before this period. Despite the lack of archaeological evidence, there are several indications for the presence of (natural or man-made) fires in the forest and grass vegetation. Nymphaeaceae seeds and tubers may have been consumed by early Mesolithic people.

\section{Acknowledgements}

The investigation at the Haelen record was supported by the Research Council for Earth and Life Science (ALW) with financial aid from The Netherlands Organisation for Scientific Research (NW0, project No. 8811.32.002). We would like to thank Annemarie Philip for preparing the microfossil samples and Nico de Wilde de Ligny for the LOI analyses. Cyriel Verbruggen and Nathalie van der Putten are thanked for coring the Haelen sequence and enabling the subsampling of the lower part of the Haelen sequence. Frieda Zuidhoff and Eric Drenth are thanked 
for useful suggestions, and Annette Botman for the construction of Figure 1. We also thank Lineke Woelders and an anonymous referee for constructive comments on an earlier version of this paper.

\section{References}

Anderberg, A.L., 1994. Atlas of seeds and small fruits of northwestEuropean plant species with morphological descriptions. Part 4, ResedaceaeUmbelliferae. Swedish Museum of Natural History. Risbergs Tryckeri AB (Uddevalla): $281 \mathrm{pp}$.

Bats, M., Crombé, Ph., Devriendt, I., Langohr, R., Mikkelsen, J.H., Ryssaert, C. \& Van de Water, A., 2010. Een vroegmesolithische vindplaats te HaelenBroekweg (gem. Leudal., provincie Limburg). Rapportage Archeologische Monumentenzorg 190: 202 pp.

Behre, K.E., 1966. Untersuchungen zur spätglazialen und frühpostglazialen Vegetationsgeschichte 0stfrieslands. Eiszeitalter und Gegenwart 17: 69-84.

Behre, K.E., 1978. Die Klimaschwankungen im europäischen Präboreal. Petermans Geographische Mitteilungen 2: 97-102.

Beijerinck, W., 1947. Zadenatlas der Nederlandse Flora, ten behoeve van de botanie, palaeontologie, bodemcultuur en warenkennis. Backhuys \& Meesters (Amsterdam): $316 \mathrm{pp}$.

Berggren, G., 1969. Atlas of seeds and small fruits of Northwest-European plant species with morphological descriptions. Part 2, Cyperaceae. Swedish Natural Science Research Council, Stockholm. Berlingska Boktryckeriet (Lund): 68 pp.

Berggren, G., 1981. Atlas of seeds and small fruits of Northwest-European plant species with morphological descriptions. Part 3, Salicaceae-Cruciferae, Swedish Natural Science Research Council, Stockholm. Berlings (Arlöv): 261 pp.

Björck, S., Kromer, B., Johnsen, S., Bennike, O., Hammarlund, D., Lehmdahl, G., Possnert, G., Rasmussen, T.L., Wohlfarth, B., Hammer, C.U. \& Spurk, M., 1996. Synchronized terrestrial-atmospheric deglacial records around the North Atlantic. Science 274: 1155-1160.

Björck, S., Rundgren, M., Ingólfsson, ó. \& Funder, S., 1997. The Preboreal oscillation around the Nordic seas: terrestrial and lacustrine responses. Journal of Quaternary Science 12: 455-465.

Blaauw, M., Heuvelink, G.B.M., Mauquoy, D., van der Plicht, J. \& van Geel, B. 2003. A numerical approach to ${ }^{14} \mathrm{C}$ wiggle-match dating of organic deposits: best fits and confidence intervals. Quaternary Science Reviews 22: 1485-1500.

Blaauw, M., van Geel, B., Mauquoy, D. \& van der Plicht, J., 2004. Carbon-14 wiggle-match dating of peat deposits: advantages and limitations. Journal of Quaternary Science 19: 177-181.

Blokker, A.C.M., 2013. Climate related fluvial changes of the Meuse and vegetation development in the Late-Glacial and Holocene. Master thesis Vrije Universiteit Amsterdam (Amsterdam) (internal report).

Bohncke, S.J.P. \& Hoek, W.Z., 2007. Multiple oscillations during the Preboreal as recorded in a calcareous gyttja, Kingbeekdal, The Netherlands. Quaternary Science Reviews 26: 1965-1974.

Bos, J.A.A., 1992. Palynological studies in the development of the vegetation around archaeological sites in Noord-Brabant and Limburg (the Netherlands) during the Late Glacial and Early Holocene, Universiteit Utrecht (Utrecht) (internal report).
Bos, J.A.A., 1998. Aspects of the Lateglacial-Early Holocene vegetation development in western Europe. LPP Contributions series 10. PhD Thesis. Universiteit Utrecht (Utrecht): $240 \mathrm{pp}$.

Bos, J.A.A., 2001. Lateglacial and Early Holocene vegetation history of the northern Wetterau and the Amöneburger Basin (Hessen), central-west Germany. Review of Palaeobotany and Palynology 115: 177-212.

Bos, J.A.A. \& Urz., R., 2003. Late Glacial and early Holocene environment in the middle Lahn river valley (Hessen, central-west Germany) and the local impact of early Mesolithic people - pollen and macrofossil evidence. Vegetation History and Archaeobotany 12, 19-36.

Bos, J.A.A \& Zuidhoff, F.S., 2015. De restgeul van Well-Aijen. Een reconstructie van de vegetatieontwikkeling van het Noord-Limburgse Maasdal gedurende het Holoceen (Mesolithicum-Vroeg Romeinse tijd). ADC-rapport 3599: 92 pp.

Bos, J.A.A., Huisman, D.J., Kiden, P., Hoek, W.Z. \& van Geel, B., 2005a. Early Holocene environmental change in the Kreekrak area (Zeeland, SWNetherlands): a multi-proxy analysis. Palaeogeography, Palaeoclimatology, Palaeoecology 227: 259-289.

Bos, J.A.A., van Geel, B., Groenewoudt, B.J. \& Lauwerier, R.C.G.M., 2005b. Early Holocene environmental change, the presence and disappearance of early Mesolithic habitation near Zutphen (The Netherlands). Vegetation History and Archaeobotany 15: 27-43.

Bos, J.A.A., Bohncke, S.J.P. \& Janssen, C.R., 2006. Lake level fluctuations and small-scale vegetation patterns during the Lateglacial in The Netherlands. Journal of Paleolimnology 35, 211-238.

Bos, J.A.A., van Geel, B., van der Plicht, J.H. \& Bohncke, S.J.P., 2007. Preboreal climate oscillations in Europe: wiggle-match dating and synthesis of Dutch high-resolution multi-proxy records. Quaternary Science Reviews 26: 19271950.

Bos, J.A.A., Bouman, M.T.I.J. \& Moolhuizen, C., 2008. Archeobotanisch onderzoek. In: Prangsma, N.M. (ed.): Lomm, Hoogwatergeul Fase 1. ADC-rapport 1344: 96-110.

Bos, J.A.A, Zuidhoff, F.S., van Kappel, K. \&. Gerrets, D.A., 2012. The reconstruction of a buried Maas river landscape near Lomm (Limburg, The Netherlands) using a multi-disciplinary approach; human adaption to landscape changes. eTopoi 3: 31-38.

Bouma, N. \& Müller, A.M., 2014: Tienduizend jaar landschaps- en bewoningsgeschiedenis in het Maasdal tussen Well en Aijen. Een archeologische opgraving te Well-Aijen Hoogwatergeul werkvak 4. ADC-rapport 3472: 285 pp.

Buijs, J.T.P.J., 2013. How did climate and vegetation influence the fluvial characteristics of the Meuse River in the Roer Valley Graben during the transition from the Late Glacial to the Holocene? Master Thesis. Vrije Universiteit Amsterdam (Amsterdam) (internal report).

Dansgaard, W., Johnsen, S.J., Clausen, H.B., Dahl-Jensen, D., Gundestrup, N.S., Hammer, C.U., Hvidberg, C.S., Steffensen, J.P., Sveinbjörndottir, A.E., Jouzel, J. \& Bond, G., 1993. Evidence for general instability of past climate from a 250-kyr ice-core record. Nature 364: 218-220.

Davies, S.M., Brancj, N.P., Lowe, J.J. \& Turney, C.S.M., 2002. Towards a European tephrochronological framework for Termination 1 and the Early Holocene. Philosophical Transactions of the Royal Society of London A 360: 767-802.

Davies, S.M., Hoek, W.Z., Bohncke, S.J.P., Lowe, J.J., Pyne O'Donnell, S. \& Turney, C.S.M., 2005. Detection of Late-glacial distal tephra layers in The Netherlands. Boreas 34: 123-135. 
Day, S.P., 1993. Preliminary results of high-resolution palaeoecological analyses at Star Carr, Yorkshire. Cambridge Archaeological Journal 3: 129-133.

Day, S.P. \& Mellars, P.A., 1994. 'Absolute' dating of mesolithic human, activity at Star Carr, Yorkshire: new palaeoecological studies, and identification of the 9600 BP radiocarbon 'plateau'. Proceedings of the Prehistoric Society 60: 417-422.

Faegri, K. \& Iversen, J., 1989. Textbook of pollen analysis, 4th edn (revised by Faegri, K., Kaland, P.E. and Krzywinski, K.). Wiley \& Sons (Chichester): $328 \mathrm{pp}$.

Francis, D.R., 2001. Bryozoan statoblasts. In: Smol, J.P., Borks, H.J.B. \& Last, W.M. (eds): Tracking environmental change using lake sediments. Volume 4: Zoological indicators. Kluwer Academic Publishers (Dordrecht): 105-123.

Grimm, E.C., 1991-2004. TILIA, TILA.GRAPH, and TGView. Illinois State Museum, Research and Collections Center, Springfield, USA. Available at http://demeter.museum.state.il.us/pub /grimm.

Hannon, G.E. \& Gaillard, M.-J., 1997. The plant macrofossil record of past lakelevel changes. Journal of Paleolimnology 18: 15-28.

Hoek, W.Z., 1997a. Palaeogeography of Lateglacial vegetations - aspects of Lateglacial and Early Holocene vegetation, abiotic landscape, and climate in The Netherlands. Netherlands Geographical Studies 230: 147 pp.

Hoek, W.Z., 1997b. Atlas to palaeogeography of Lateglacial vegetations - maps of Lateglacial and Early Holocene landscape and vegetation in The Netherlands, with an extensive review of available palynological data. Netherlands Geographical Studies 231: 165 pp.

Hoek, W.Z. \& Bohncke, S.J.P., 2002. Climatic and environmental events over the Last Termination, as recorded in The Netherlands; a review. Netherlands Journal of Geosciences 81: 123-137.

Hoek, W.Z., Lammertsma, E.I., Bohncke, S.J.P., Bos, J.A.A., Bunnik, F.P.M., Kasse, C., Schokker, J. \& Westerhoff, W., 2016. Late-glacial and Early Holocene vegetation development and fluvial system changes in the northern Meuse Valley, The Netherlands: a review of palynological data. Netherlands Journal of Geosciences / Geologie en Mijnbouw, this issue.

Janssen, C.R., 1973. Local and regional pollen deposition. In: Birks, H.J.B. \& West, R.G. (eds): Quaternary plant ecology. Blackwell Scientific Publications (0xford): 31-42.

Johnsen, S.J., Clausen, H.B., Dansgaard, W., Gundestrup, N.S., Hammer, C.U. Andersen, U., Andersen, K.K., Hvidberg, C.S., Dahl-Jensen, D., Steffensen, J.P., Shoji, H., Sveinbjörnsdöttir, A.E., White, J.W.C., Jouzel, J. \& Fisher, D., 1997. The $\delta^{18} 0$ record along the Greenland Ice Core Project deep ice core and the problem of possible Eemian climate instability. Journal of Geophysical Research 102: 26397-26410.

Komárek, J. \& Jankovská, V., 2001. Review of the green algal genus Pediastrum; implication for pollen analytical research. Bibliotheca Phycologica 108: $127 \mathrm{pp}$.

Körber-Grohne, U., 1987. Nutzpflanzen in Deutschland. Kulturgeschichte und Biologie. Theiss Verlag (Stuttgart): $490 \mathrm{pp}$.

Kubiak-Martens, K., 1996. Evidence for possible use of plant foods in Palaeolithic and Mesolithic diet from the site of Calowanie in the central part of the Polish Plain. Vegetation History and Archaeobotany 5: 33-38.

Kubiak-Martens, $K_{.}, 1999$. The plant food component of the diet at the late Mesolithic (Ertebølle) settlement at Tybrind Vig, Denmark. Vegetation History and Archaeobotany 8: 117-127.
Kubiak-Martens, L., 2015. Mesolithic diet. In: Bescherer-Methèny, K. \& Beaudry, M.C. (eds): The archaeology of food: an encyclopedia. Rowman and Littlefield (Lanham, MD): 312-316.

Magny, M., Vannière, B., de Beaulieu, J.-L., Bégeot, C., Heiri, O., Millet, L., Peyron, 0. \& Walter-Simonnet, A.-V., 2007. Early-Holocene climatic oscillations recorded by lake-level fluctuations in west-central Europe and in central Italy. Quaternary Science Reviews 26: 1951-1964.

Moore, P.D., Webb, J.A. \& Collinson, M.E., 1991. Pollen analysis, 2nd edn. Blackwell (0xford): $216 \mathrm{pp}$.

Nilsson, 0. \& Hjelmqvist, H., 1967. Studies on the nutlet structure of south Scandinavian species of Carex. Botaniska Notiser 120: 460-485.

North Greenland Ice Core Project (NGRIP) members, 2004. High resolution record of Northern Hemisphere climate extending into the last interglacial period. Nature 431: 147-151.

Oberdorfer, E., 1990. Pflanzensoziologische Exkursionsflora. Ulmer (Stuttgart): $1050 \mathrm{pp}$.

Otten, S.P.M., 2013. Fluvial response of the river Maas to Lateglacial and Early Holocene climate and vegetation changes in Limburg, S-Netherlands. Master Thesis. Universiteit Utrecht (Utrecht).

Out, W., 2008. Gathered food plants at Dutch Mesolithic and Neolithic wetland sites. In: Baker, S., Allen, M., Middle, S. \& Poole, K. (eds): Food and drink in archaeology 1: a post-graduate conference. Prospect Books (Totnes): 84-95.

Out, W.A., 2009. Evidence of human impact and plant subsistence from macroremains: use plants and food plants from the natural vegetation. In: Sowing the seed?: human impact and plant subsistence in Dutch wetlands during the Late Mesolithic and Early and Middle Neolithic (5500-3400 cal BC). PhD Thesis. Universiteit Leiden. Leiden University Press (Leiden): 331-379.

Punt, W. et al., 1976-2003. The northwest European pollen flora, vol. I (1976); vol. II (1980); vol. III (1981); vol. IV (1984); vol. V (1988); vol. VI (1991); vol. VII (1995); vol. VIII (2003). Elsevier Scientific Publishing Company (Amsterdam): 145 pp.; 265 pp.; 138 pp.; 369 pp.; 154 pp.; 275 pp.; 282 pp.; 194 pp.

Rasmussen, S.O., Andersen, K.K. Svenson, A.M., Steffensen, J.P., Vinther, B.M., Johnsen, S.J., Clausen, H.B., Larsen, L.B., Bigler, M., Röthlisberger, R., Andersen, M.-L.S., Fisher, H., Ruth, U., Goto-Azuma, K. \& Hansson, M., 2006. A new Greenland ice core chronology for the last glacial termination. Journal of Geophysical Research 111, D06102. doi:10.1029/2005JD006079.

Rasmussen, S.O., Vinther, B.M., Clausen, H.B. \& Andersen, K.K., 2007. Early Holocene climate oscillations recorded in three Greenland ice cores. Quaternary Science Reviews 26: 1907-1914.

Rasmussen, S.O., Abbott, P.M., Blunier, T., Bourne, A.J., Brook, E., Buchardt, S.L., Buizert, C., Chappellaz, J., Clausen, H.B., Cook, E., Dahl-Jensen, D., Davies, S.M., Guillevic, M., Kipfstuhl, S., Laepple, T., Seierstad, I.K., Severinghaus, J.P., Steffensen, J.P., Stowasser, C., Svensson, A., Vallelonga, P., Vinther, B.M., Wilhelms, F., \& Winstrup, M., 2013. A first chronology for the North Greenland Eemian Ice Drilling (NEEM) ice core. Climate of the Past 9: 2713-2730.

Renfrew, J.M., 1973. Palaeoethnobotany. The prehistoric food plants of the Near East and Europe. Methuen (London): 248 pp.

Renssen, H. \& Isarin, R.F.B., 2001. The two major warming phases of the last deglaciation at $\sim 14.7$ and $\sim 11.5 \mathrm{ka}$ cal BP in Europe: climate reconstructions and AGCM experiments. Global and Planetary Change 30: 117-153. 
Scheurs, J., 2013. Omleiding N273-Haelen. Jagers, verzamelaars en boeren uit de prehistorie te Haelen-Napoleonsweg (gem. Leudal, provincie Limburg). Rapportage Archeologische Monumentenzorg 217: 208 pp.

Schweingruber, F.H., 1978. Mikroskopische Holzanatomie. F. Flück-Wirth (Teufen): $226 \mathrm{pp}$.

ter Wal, A. \& Tebbens, L.A., 2012. Well-Aijen Werkvak 1, archeologische opgraving. BAAC rapport A-09.0395: 302 pp.

Simmons, I.G., 1993. Vegetation change during the Mesolithic in the British Isles: some amplifications. In: Chambers, F.M. (ed.): Climate change and human impact on the landscape. Chapman \& Hall (London): 109-118.

Simmons, I.G., Turner, J. \& Innes, J.B., 1989. An application of fine resolution pollen analysis to Later Mesolithic peats of an English upland. In: Bonsall, C. (ed.): The Mesolithic in Europe. Donald (Edinburgh): 206-217.

Teunissen, $\boldsymbol{D}$., 1983. The development of the landscape of the nature reserve 'de Hamert' and its environs in the northern part of the province of Limburg, the Netherlands. Geologie en Mijnbouw 62: 569-576.

Teunissen, D., 1990. Palynologisch onderzoek in het oostelijk rivierengebied; een overzicht. Mededelingen van de Afdeling Biogeologie van de Discipline Biologie van de Katholieke Universiteit van Nijmegen. Mededeling 16: 166 pp.

van der Hammen, T., 1951. Late-glacial flora and periglacial phenomena in The Netherlands. Leidse Geologische Mededelingen 17: 71-183.

van der Meijden, R., 1996. Heukels' flora van Nederland. Wolters-Noordhoff (Groningen): $276 \mathrm{pp}$.

van der Plicht, J., van Geel, B., Bohncke, S.J.P., Bos, J.A.A., Blaauw, M., Speranza, A.O.M., Muscheler, R. \& Björck, S., 2004. The Preboreal climate reversal and a subsequent solar forced climate shift. Journal of Quaternary Science 19: 263-269.

van Geel, B., 1978. A paleoecological study of Holocene peat bog sections in Germany and The Netherlands. Review of Palaeobotany and Palynology 25: $1-120$.

van Geel, B., 2001. Non-pollen palynomorphs. In: Smol, J.P., Birks, H.J.B. \& Last, W.M. (eds) Tracking environmental change using lake sediments; Volume 3: Terrestrial, algal and silicaceous indicators. Kluwer (Dordrecht): 99-119.

van Geel, B. \& Aptroot, A., 2006. Ascomycetes in Quaternary deposits. Nova Hedwigia 82: 313-329.

van Geel, B. \& Kolstrup, E. 1978. Tentative explanation of the Late Glacial and Early Holocene climate changes in north-western Europe. Geologie en Mijnbouw 57: 87-89.

van Geel, B. \& Mook, W.G., 1989. High-resolution ${ }^{14} \mathrm{C}$ dating of organic deposits using natural atmospheric ${ }^{14} \mathrm{C}$ variations. Radiocarbon 31: 151-155.

van Geel, B., Bohncke, S.J.P. \& Dee, H., 1981. A palaeoecological study of an upper Late Glacial and Holocene sequence from 'De Borchert', The Netherlands. Review of Palaeobotany and Palynology 31: 367-448.

van Geel, B., Hallewas, D.P. \& Pals, J.P., 1983. A Late Holocene deposit under the Westfriese Zeedijk near Enkhuizen (Prov. of N-Holland, The Netherlands): palaeoecological and archaeological aspects. Review of Palaeobotany and Palynology 38: 269-335. van Geel, B., Coope, G.R. \& van der Hammen, T., 1989. Palaeoecology and stratigraphy of the Lateglacial type section at Usselo (The Netherlands). Review of Palaeobotany and Palynology 60: 25-129.

van Geel, B., Buurman, J., Brinkkemper, 0., Schelvis, J., Aptroot, A., van Reenen, G.B.A. \& Hakbijl, T., 2003. Environmental reconstruction of a Roman Period settlement site in Uitgeest (The Netherlands), with special reference to coprophilous fungi. Journal of Archaeological Science 30: 873-883.

van Haaster, H., 2011. Archeobotanisch onderzoek in het plangebied Well AijenHoogwatergeul 1 A/B (Neolithicum-Romeinse tijd). Biaxiaal 546: 20 pp.

Verbruggen, C., Van Der Putten, N. \& Warreyn, M., 2003. Palynologisch onderzoek van de oude Maas-arm te Haelen - Nederlands Limburg. Ministerie van Verkeer en Waterstaat, Nederland.

Verhart, L., 2008. New developments in the study of the Mesolithic of the Low Countries. In: Bailey, G. \& Spikins, P. (eds): Mesolithic Europe. Cambridge University Press (Cambridge): 158-181.

Weeda, E.J., Westra, R., Westra, Ch. \& Westra, T., 1987. Nederlandse oecologische flora. Wilde planten en hun relaties 2. IVN uitgave (Deventer): 304 pp.

Weeda, E.J., Westra, R., Westra, Ch. \& Westra, T., 1988. Nederlandse oecologische flora. Wilde planten en hun relaties 3. IVN uitgave (Deventer): 302 pp.

Wijmstra, T.A. \& de Vin, A., 1971. De new Dinkel canal section. In: van der Hammen, T. \& Wijmstra, T.A. (eds), Upper Quaternary of the Dinkel Valley. Medelingen Rijks Geologische Dienst NS 22: 101-129.

Woelders, L., Bos, J.A.A., de Kort, J.-W. \& Hoek, W.Z., 2015. Early Holocene environmental change and the presence of Mesolithic people in the Tungelroyse Beek valley near Mildert, the Netherlands. Vegetation History and Archaeobotany 25: 177-189.

Zuidhoff, F.S. \& Bos, J.A.A., 2011a. Landschap en vegetatie. Lomm Hoogwatergeul fase II. In: Gerrets, D.A. \& de Leeuwe, $\boldsymbol{R}$. (eds): Rituelen aan de Maas. Lomm Hoogwatergeul fase II, een archeologische opgraving. ADC-rapport 2333: 27-61.

Zuidhoff, F.S. \& Bos, J.A.A., 2011b. Landschap en vegetatie. In: Gerrets, D.A. \& Williams, G.L. (eds): Water en Vuur. Archeologisch proefsleuvenonderzoek en opgraving te Lomm Hoogwatergeul Fase III. ADC-rapport 2703: 27-66.

Zuidhoff, F.S. \& Bos, J.A.A., 2014. Landschap en vegetatie. In: Bouma, N. \& Müller, A.M. (eds): Tienduizend jaar landschaps- en bewoningsgeschiedenis in het Maasdal tussen Well en Aijen. Een archeologische opgraving te WellAijen Hoogwatergeul werkvak 4. ADC-rapport 3472: 57-78.

Zuidhoff, F.S. \& Bos, J.A.A., 2016. Sedimentation and vegetation history of a buried Meuse terrace during the Holocene in relation to the occupation history (Limburg, The Netherlands). Netherlands Journal of Geosciences / Geologie en Mijnbouw, this issue.

Zuidhoff, F.S. \& Huizer, J., 2015. De noordelijke Maasvallei door de eeuwen heen. Vijftienduizend jaar landschapsdynamiek tussen Roermons en Mook. Inventariserend archeologisch onderzoek 'Verkenning Plus' Project Maasvallei voor vijftien deelgebieden. ADC-Monografie 19 / ADC-rapport 3750: 490 pp. 